University of Nebraska - Lincoln

DigitalCommons@University of Nebraska - Lincoln

Faculty Publications from the Harold W. Manter Laboratory of Parasitology

2005

Phylogeny for Genera of Nematodirinae (Nematoda: Trichostrongylina)

\author{
Eric P. Hoberg \\ United States Department of Agriculture, Agricultural Research Service, geocolonizer@gmail.com \\ J. Ralph Lichtenfels \\ United States Department of Agriculture, Agricultural Research Service
}

Lora G. Rickard

Mississippi State University

Follow this and additional works at: https://digitalcommons.unl.edu/parasitologyfacpubs

Part of the Parasitology Commons

Hoberg, Eric P.; Lichtenfels, J. Ralph; and Rickard, Lora G., "Phylogeny for Genera of Nematodirinae (Nematoda: Trichostrongylina)" (2005). Faculty Publications from the Harold W. Manter Laboratory of Parasitology. 665.

https://digitalcommons.unl.edu/parasitologyfacpubs/665

This Article is brought to you for free and open access by the Parasitology, Harold W. Manter Laboratory of at DigitalCommons@University of Nebraska - Lincoln. It has been accepted for inclusion in Faculty Publications from the Harold W. Manter Laboratory of Parasitology by an authorized administrator of DigitalCommons@University of Nebraska - Lincoln. 


\title{
PHYLOGENY FOR GENERA OF NEMATODIRINAE (NEMATODA: TRICHOSTRONGYLINA)
}

\author{
Eric P. Hoberg, J. Ralph Lichtenfels, and L. G. Rickard ${ }^{\star}$
}

U.S. National Parasite Collection, and the Animal Parasitic Diseases Laboratory, USDA, Agricultural Research Service, BARC East No.1180, 10300 Baltimore Avenue, Beltsville, Maryland 20705-2350. e-mail: ehoberg@anri.barc.usda.gov

\begin{abstract}
Monophyly for the Nematodirinae, with 5 genera, Murielus, Rauschia, Nematodiroides, Nematodirus, and Nematodirella was confirmed based on comparative morphology and phylogenetic analysis of structural characters. This concept for the nematodirines excludes the monotypic Lamanema chavezi, but otherwise corroborates generic-level diversity as defined in prior studies. Exhaustive analysis resulted in 1 most parsimonious tree (36 steps; consistency index $[\mathrm{CI}]=0.94$; retention index [RI] $=0.93$; excluding phylogenetically uninformative characters, $\mathrm{CI}=0.92)$. As an inclusive or monophyletic group, Nematodirinae was diagnosed by 8 synapomorphies ( 7 are unequivocal): (1) large eggs, (2) long filiform spicules, (3) basal division of the dorsal ray, (4) symmetrical membrane enveloping the spicule tips, (5) fused structure of the spicule tips, (6) absence of the gubernaculum, (7) development of the third-stage larva within the egg, and (8) ornamentation in the form of discrete bosses on the bursa. Exclusion of Lamanema will require new assessments of historical biogeography and the evolution of host associations for the nematodirines.
\end{abstract}

Nematodirine nematodes globally represent serious pathogens in wild mammals and domestic stock. The speciose genus Nematodirus Ransom, 1907, contains an array of helminth pathogens that infect ruminants throughout the world, and species such as Nematodirus battus Crofton and Thomas, 1951, continue to be regarded as among the most economically significant parasites in domestic sheep, Ovis aries Linnaeus, across the Northern Hemisphere (e.g., Thomas and Stevens, 1956; Hoberg, Zimmerman, and Rickard, 1985; Hoberg, 1997). Although there has been considerable effort and research to define epizootiology, and the host-parasite interface for species of Nematodirus (e.g., Thomas, 1959; Rickard et al., 1989), our understanding of the broader evolution and history for these and related nematodes remains to be fully elucidated.

Current taxonomy and concepts for the relationships of the Nematodirinae Skrjabin and Orloff, 1937, were established by Durette-Desset and Chabaud (1977, 1981a) and Durette-Desset (1983). Durette-Desset and Chabaud (1977, 1981b) elevated the Molineinae Skrjabin and Shul'ts 1937 to establish the family Molineidae (Trichostrongyloidea), which contained the Nematodirinae, Molineinae Skrjabin and Shul'ts, 1937, and several other subfamilies. Durette-Desset and Chabaud (1977, 1981a) and Durette-Desset $(1983,1985)$ refined the concept for $\mathrm{Ne}$ matodirinae and recognized 6 inclusive or monophyletic genera: Nematodirus (type); Nematodirella Yorke and Maplestone, 1926; Murielus Dikmans, 1939; Lamanema Becklund, 1963; Nematodiroides Bernard, 1967; and Rauschia Durette-Desset, 1979. Subsequent proposals for taxonomic revision within the Trichostrongyloidea resulted in elevation of the superfamily to a subordinal rank within Strongylida. Concurrently, 3 taxa of superfamily rank, Molineoidea, Trichostrongyloidea, and Heligmosomoidea, were established to recognize putative monophyletic lineages within the Trichostrongylina (Durette-Desset and Chabaud, 1993). Although this concept for elevated taxonomic rank has not been universally accepted, the Nematodirinae is thus contained within the Molineoidea and Molineidae (see Durette-Desset et al., 1994).

Durette-Desset and Chabaud (1981a) presented the first explicit hypothesis for relationships within the Trichostrongylo-

Received 22 March 2004; revised 20 July 2004; accepted 20 July 2004.

* College of Veterinary Medicine, P.O. Box 9825, Mississippi State University, Mississippi State, Mississippi 39762. idea and indicated, among the molineids, a putative sister-group relationship for Nematodirinae and Molineinae + Anoplostrongylinae; Molineidae was regarded as the putative sister of the Trichostrongylidae (Durette-Desset, 1985). Subsequent to establishment of the Trichostrongylina, Durette-Desset et al. (1994) modified these concepts to recognize 3 lineages with unspecified relationships linking the Trichostrongyloidea, Molineoidea, and Heligmosomoidea in a basal polytomy within the Trichostrongylina. Gouÿ de Bellocq et al. (2001) provided resolution among these taxa, suggesting monophyly for the respective lineages based on a single-locus analysis. Significantly, relatively robust phylogenetic support for 2-3 major clades, representing the Heligmosomoidea + Molineoidea and the Trichostrongyloidea, has been inferred based on partial sequences from $28 \mathrm{~S}$ rDNA (Gouÿ de Bellocq et al., 2001). The latter, in part, provides the foundation for selection of potential outgroups suitable for phylogenetic analyses within the Nematodirinae in the current study.

Nematodirines have been diagnosed by a suite of attributes of the anterior esophagus (neodont), synlophe, bursa, and ovejectors that encompass both putative plesiomorphic and apomorphic character states (e.g., Durette-Desset, 1985). Rickard and Hoberg (2000) suggested, in conjunction with preliminary outgroup comparisons relative to the Trichostrongylidae and Molineidae, that 7 characters may constitute synapomorphies for the Nematodirinae: (1) presence of perioral denticles, (2) long filiform spicules, (3) fusion of spicule tips, (4) symmetrical membrane enveloping spicule tips, (5) dorsal ray divided and separated at base, (6) absence of gubernaculum, and (7) large eggs. Based on an assessment of these criteria, it was proposed that the monotypic Lamanema, with Lamanema chavezi Becklund, 1963, be excluded from the subfamily (referred to Molineinae), leaving Nematodirinae with 5 genera (Rickard and Hoberg, 2000).

Explicit phylogenetic studies among the genera of the nematodirines have not been presented, although scenarios for some aspects of evolution, host relationships, and historical biogeography within the subfamily have been summarized (e.g., Durette-Desset, 1978, 1979, 1985; Rossi, 1983; Durette-Desset et al., 1994). A comprehensive phylogeny for species of $\mathrm{Ne}$ matodirella was completed by Lichtenfels and Pilitt (1983b). Nematodirus has been the subject of phylogenetic studies emphasizing those species in domestic ruminants (e.g., Lichtenfels and Pilitt, 1983a). Nematodirus was also the focus of analyses 
TABLE I. Specimens examined in a phylogenetic study of Nematodirinae.

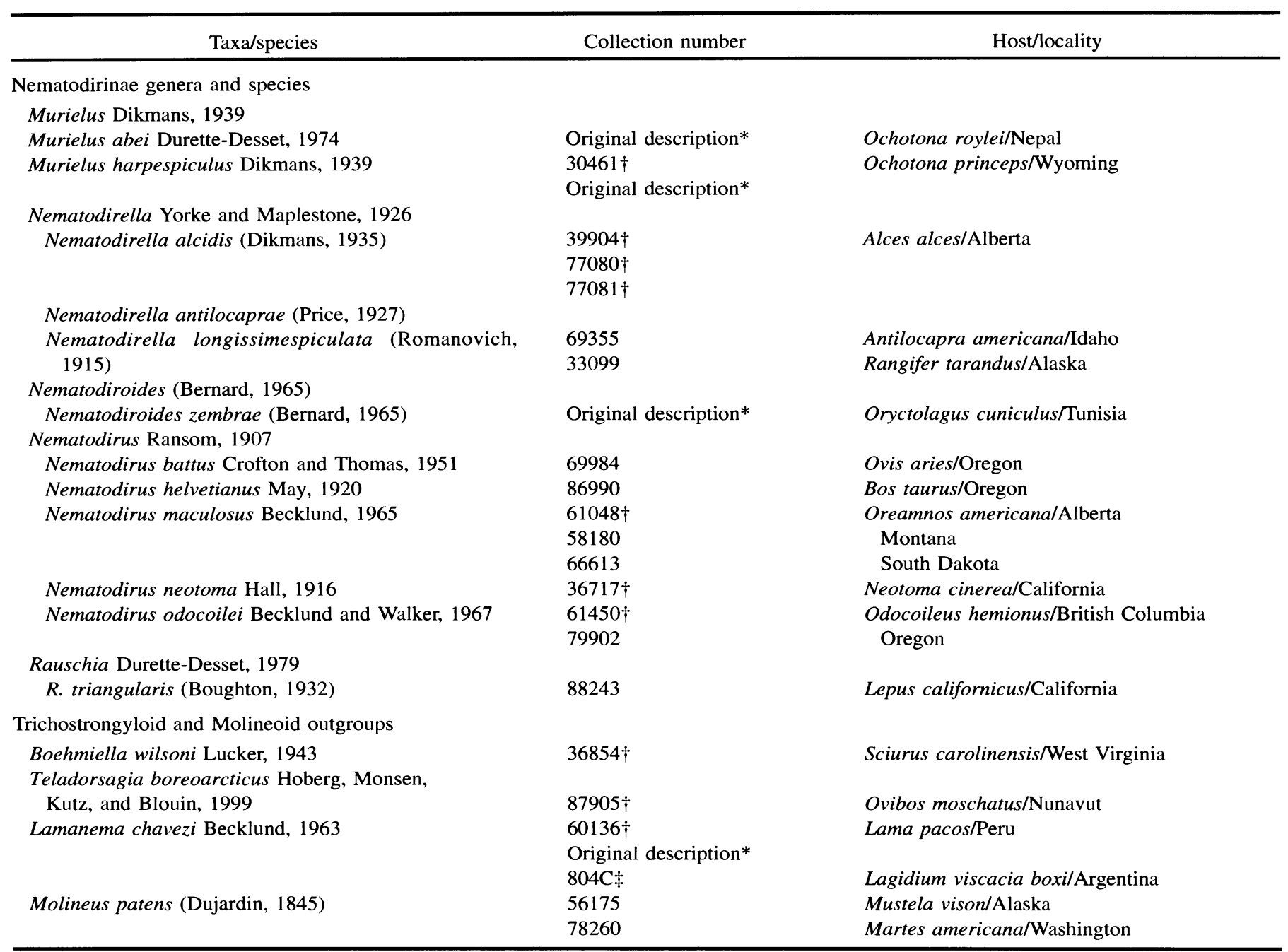

* Original descriptions: Durette-Desset (1974) for Murielus abei; Dikmans (1939) for Murielus harpespiculus; Bernard (1967) for Nematodiroides zembrae; Becklund, (1963) and Sutton and Durette-Desset (1985) for L. chavezi. Specimens examined from the U.S. National Parasite Collection unless noted otherwise.

$\dagger$ Type specimens examined.

¥ Specimens from Universidad Nacional de La Plata, Collection Helmintologia del Muséo de La Plata, Argentina.

exploring the relationships of representative species parasitizing camelids, cervids, and caprines and the putative origin and history for host association and geographic distribution for the pathogen Nematodirus battus (Hoberg, 1997). Additionally, taxonomically limited comparisons based on data from nuclear ribosomal sequences were conducted to reveal relationships for populations of Nematodirus battus in domestic sheep and the contemporary determinants of geographic distribution in the Holarctic (Audebert et al., 2000; Nadler et al., 2000).

Although monophyly has been assumed, there has been no universal test of this hypothesis for the Nematodirinae. The remaining subfamilies of the Molineidae also lack an unequivocal phylogenetic basis; and synapomorphies for constituent taxa, including Anoplostrongylinae, Molineinae, and Ollulaninae, have not been defined (Rickard and Hoberg, 2000). In the current study, we explore the applicability of characters derived from comparative morphology in (1) providing a phylogenetic diagnosis for the Nematodirinae, (2) testing the hypothesis for exclusion of Lamanema, and (3) development of hypotheses for relationships among genera of the subfamily.

\section{MATERIALS AND METHODS}

Phylogenetic analysis of morphological characters was used to examine the putative relationships among adult nematodes representing 5 genera of the Nematodirinae (Table I). Characters were derived from examination of specimens of exemplar species in addition to data in original descriptions and redescriptions (e.g., Travassos, 1937; Skrjabin, Shikhobalova, and Shul'ts, 1954; Durette-Desset, 1979; Lichtenfels and Pilitt, 1983a, 1983b; Sutton and Durette-Desset, 1985). Standard methods for comparative morphology among the putative genera of the $\mathrm{Ne}$ matodirinae and outgroups are outlined in Chabaud et al. (1967), Durette Desset (1974, 1979), Durette-Desset and Chabaud (1981a), and Lichtenfels and Pilitt (1983a, 1983b). A putative relationship for $L$. chavezi in the context of the in-group was examined, although previous comparative studies relegated this monotypic genus to the Molineinae (Rickard and Hoberg, 2000).

Characters included morphological attributes typical of male and female nematodes. Polarity was estimated based on taxonomic outgroup comparisons (Watrous and Wheeler, 1981; Maddison et al., 1984); mul- 
TABLE II. Character matrix for genera of Nematodirinae.

\begin{tabular}{lcc}
\hline & \multicolumn{2}{c}{ Characters $(1-23)$} \\
\cline { 2 - 3 } \multicolumn{1}{c}{ Genus } & 12345678911 & 111111112222 \\
\hline Trichostrongyloidea* & 01 & 234567890123 \\
Molineoidea* & $0000000000 \phi$ & $00000 \phi 001100$ \\
Murielus & $00000001110 \& 1$ & 111100000011 \\
Nematodirella & 11000102220 & 211111000011 \\
Nematodiroides & 11121000310 & 211212100011 \\
Nematodirus & $11000112020 \& 1$ & 111111000011 \\
Rauschia & 11111000020 & 111110000011 \\
Lamanema $\dagger$ & 20000000030 & 000000011221 \\
Lamanema $\ddagger$ & 10000000010 & 000000011111 \\
\hline
\end{tabular}

* Taxonomic outgroups; see Table I for exemplar species examined. Coding represents estimation of ancestral states for species in Trichostrongyloidea and Molineoidea, respectively. $\phi=$ inapplicable character for Trichostrongyloidea.

$\dagger$ Coding is consistent with independent derivation (convergence) in L. chavezi. These decisions influence characters $1,10,21$, and 22 and suspend application of Hennig's Auxiliary Principle (HAP).

¥ Alternative coding consistent with hypothesis for homology in $L$. chavezi, nematodirines, and outgroups. These decisions influence characters 1, 10, 21, and 22 and apply HAP.

tistate taxa were coded as polymorphic. Outgroup selection was based on phylogenetic analyses summarized in Durette-Desset et al. (1994) and Gouÿ de Bellocq et al. (2001). Multiple outgroups included species that exemplify Trichostrongyloidea and Molineoidea (Table I). Outgroups are presented as an estimation of ancestral states based on examination of multiple exemplars representing each of the superfamilies. Descriptions for 23 binary and multistate characters are presented below and in a numerical matrix (Table II). Alternatives for coding are presented for characters $1,10,21$, and 22 in $L$. chavezi and involve either suspension, consistent with putative convergence, or application of Hennig's Auxiliary Principle (Wiley et al., 1991). Hennig's Auxiliary Principle specifies that similar characters are considered to be homologous unless there is compelling evidence for convergence or parallelism (Brooks and McLennan, 2002).

Parsimony analysis was conducted with PAUP 4.0b10 for MacIntosh (Swofford, 2001). Searches were completed in the exhaustive option, with optimization by accelerated transformation; characters were unordered and with equal weights. Results are shown as a phylogenetic tree with associated statistics, including length, consistency index $(\mathrm{CI})$, and retention index $(\mathrm{RI})$. Characters and changes were mapped directly onto the most parsimonious tree (MPT) for evaluation with MacClade 4.0 (Maddison and Maddison, 2000). Tree topology and support for relationships among nematodirines were evaluated based on jackknife resampling and calculation of Bremer decay indices (Bremer, 1994). Jackknife analysis was implemented in PAUP with 10,000 replicates, branch and bound, and presentation as a strict consensus tree.

\section{Character descriptions}

1. Development of neodont formation (Durette-Desset, 1983): Two states: $0=$ dorsal esophageal gland orifice opening in buccal capsule, maybe associated with tooth or tooth is absent; 1 = neodont formation present. The neodont was designated by Durette-Desset $(1983,1985)$ to recognize a prominent cuticularized tooth arising from the dorsal aspect of the esophageal lumen; presence of the neodont is apomorphic. Such structures are not considered to be homologous across the strongyles and are represented in the Nematodirinae (all genera excluding Murielus) and a limited number of Molineoidea and Trichostrongyloidea. The neodont is present in the molineid, $L$. chavezi, which has multiple teeth, 1 dorsal and 2 lateroventral; among the trichostrongyloids, including genera and species of the Haemonchinae, there may be single or multiple teeth. In contrast, among Ostertagiinae, such as Teladorsagia and Mazamstrongylus, the dorsal esophageal tooth is present, but the neodont is absent. The ancestral condition is estimated as absence of the neodont, and the Molineoidea and Trichostrongyloidea are coded accordingly. In testing the placement of Lamanema, the presence of the neodont was either coded as present $(=1)$, or present and independently derived, representing a hypothesis for convergent acquisition of this attribute $(=2)$; see alternative coding in Table II.

2. Perioral denticles: Two states: $0=$ absent; $1=$ present. Also referred to as the corona radiata, this attribute is present in all putative nematodirines except Murielus. Perioral denticles are largely unknown among other Molineoidea and Trichostrongyloidea (Durette-Desset and Chabaud, 1981a, 1981b; Durette-Desset, 1983; Durette-Desset et al., 1999), and their presence in nematodirines is considered to represent the apomorphic condition (see Durette-Desset, 1985; Rickard and Hoberg, 2000).

3. Synlophe orientation: Two states: $0=$ perpendicular to body surface; 1 = oblique to body surface. Where the synlophe is present among Trichostrongyloidea and Molineoidea, the ridges are usually perpendicular to the surface of the body and bilaterally symmetrical, which is designated as the plesiomorphic condition (Durette-Desset, 1983, 1985).

4. Synlophe orientation: Three states: $0=$ perpendicular; $1=$ lateral and ventral ridges directed ventrally; 2 = lateral ridges directed dorsally. The orientation of the ventral ridges in species of Rauschia and Nematodiroides varies independently from the plesiomorphic condition, although a sagittal axis is apparent (Durette-Desset, 1985); orientation in Nematodiroides and Rauschia was defined as lateroventral and ventrolateral, respectively (Durette-Desset, 1983).

5. Synlophe gradient in size: Two states: $0=$ absence of gradient, ridges of equal height; 1 = gradient present, ridges vary in height along axis.

6. Synlophe, maximum numbers of ridges at midbody in reference to Molineoidea: Three states: $0=$ midbody ridges $\leq 18 ; 1=$ midbody ridges $\leq 52 ; 2=$ midbody ridges $\leq 60$. Although there is minimal overlap, the coding for this character assumes distinct differences among taxa, and a general increase in the numbers of ridges characteristic for species of Nematodirus and Nematodirella (e.g., Lichtenfels and Pilitt, 1983a, 1983b). Among Trichostrongyloidea, this character is inapplicable and is designated as $=\phi$ in the matrix (Table II).

7. Synlophe, hypertrophy in dorsal and ventral ridges: Two states: 0 $=$ ridges never hypertrophied as fins; $1=$ ridges hypertrophied and finlike. Hypertrophy of dorsal and ventral ridges is limited to some species of Nematodirus, including Nematodirus davtiani (Grigorian, 1949) and Nematodirus filicollis (Rudolphi, 1802) and is considered a putative synapomorphy for the genus, as it is a unique character among the nematodirines, although this attribute has not been evaluated in all inclusive species (see Lichtenfels and Pilitt, 1983a).

8. Vulva, position: Three states: $0=$ posterior third or fourth of body; $1=$ posterior eighth of body; 2 = midbody or anterior to midbody.

9. Uterus, development of anterior and posterior branches: Four states: $0=$ didelphic, both branches fully functional; $1=$ monodelphic (complete absence of 1 branch); $2=$ anterior branch atrophied and vestigial; 3 = posterior branch atrophied and vestigial. The monodelphic condition is observed only among Murielus, whereas the posterior or anterior branch is present but nonfunctional in Nematodiroides and Rauschia.

10. Eggs, maximum length: Three states: $0=$ length usually $\leq 100$ $\mu \mathrm{m} .1$ = length usually $\geq 150 \mu \mathrm{m}$ and $\leq 180 \mu \mathrm{m} ; 2=$ length $\geq 180 \mu \mathrm{m}$ and generally $>200 \mu \mathrm{m}$. Large eggs constitute a putative synapomorphy for Nematodirinae, although homoplasy is evident in a broader comparative context in the Strongylida. In testing the placement of Lamanema, this character was coded as apomorphic $(=1)$ or apomorphic and independently derived, consistent with a hypothesis for convergent acquisition (=3); see alternative coding in Table II.

11. Tail form in adult female in reference to Molineoidea: Two states: $0=$ tail truncate, with terminal spine; $1=$ conical, with spine absent. A truncate tail with spine is considered plesiomorphic (e.g., Hoberg and Lichtenfels, 1994; Durette-Desset et al., 1999). Multistate taxa are represented in the Nematodirinae, with both conical and truncate tails being observed in Nematodirus and Murielus. It is postulated that the derived state was independently acquired in some species of these respective genera and represents transformation of the truncate tail. For Trichostrongyloidea, $\phi=$ inapplicable (Table II).

12. Spicule, length: Three states: $0=$ short, relatively robust; $1=$ long, filiform, generally from 500 to $1,000 \mu \mathrm{m}$ in length; $2=$ extremely long, filiform, 4-12 $\mathrm{mm}$ in length. Long spicules constitute a putative synapomorphy for Nematodirinae.

13. Dorsal ray, structure: Two states: $0=$ dorsal ray not bifurcated 
at base; $1=$ dorsal ray bifurcated at base. This attribute constitutes a putative synapomorphy for Nematodirinae.

14. Spicule, membrane: Two states: $0=$ symmetrical membrane not enveloping spicule tips; 1 = symmetrical membrane enveloping spicule tips. This attribute represents a putative synapomorphy for Nematodirinae.

15. Spicule tip: Two states: $0=$ spicule tips, bifurcate or trifurcate, not fused; 1 = symmetrical and fused; $2=$ asymmetrical and fused. This constitutes a putative synapomorphy for Nematodirinae, with an autapomorphic state in Nematodiroides.

16. Gubernaculum: Two states: $0=$ present; $1=$ absent. This attribute is a putative synapomorphy for Nematodirinae.

17. Bursal rays, relative size of rays 4 and 5 in reference to Molineoidea: 3 states: $0=$ ray $4<5 ; 1=$ ray $4=5 ; 2=$ ray $4>5$. In Trichostrongyloidea, $\phi=$ inapplicable (Table II).

18. Bursal rays, structure of ray 4: Two states: $0=$ ray 4 narrow; 1 $=$ ray 4 robust.

19. Enterohepatic migration and development: Two states: $0=$ development of adult nematodes entirely within small intestine; 1 = larval migration and development in liver and bile ducts of definitive host. Lamanema chavezi completes a migration through the liver prior to completion of the molt to adult in the small intestine (Guerrero et al., 1973; Guerrero, Rojas, and Alva, 1981). Cooperia hepaticae Ortlepp, 1938, is apparently the only species among the Trichostrongyloidea or the Molineoidae that has a hepatic phase, and in this case, adult nematodes reproduce in the liver and bile ducts of ruminants (Anderson, 1992).

20. Accessory bursal membrane: Two states: $0=$ absent; $1=$ present. In $L$. chavezi, the presence of a membrane surrounding well-developed dorsal or "7" papillae is considered the apomorphic condition, consistent with the structure of this attribute among Trichostrongyloidea (see Hoberg and Lichtenfels, 1994).

21. Position of bursal rays 2 and 3: Two states: $0=$ rays 2 and 3 parallel, generally narrow; $1=$ rays 2 and 3 highly divergent, robust. Rays 2 and 3 are parallel in all nematodirines and most Molineoidea and consistent with hypotheses of Durette-Desset et al. (1999), narrow and parallel rays represent the plesiomorphic condition. In contrast, divergence of rays $2 / 3$ is characteristic in $L$. chavezi and some Trichostrongyloidea, such as Haemonchinae, but this pattern may not be homologous. Coding for $L$. chavezi is either $=1$ or $=2$, the latter to denote convergence and independent derivation for similar structures in these taxa; see alternative coding in Table II.

22. Development of third larval stage within the egg: Two states: 0 $=$ first larval stage hatches from egg; $1=$ third larval stage develops and hatches from egg. The apomorphic state is limited to nematodirines and has been documented in species of Nematodirus, Nematodirella, and Rauschia, but is currently undetermined, but predicted to occur, among species of Murielus or Nematodiroides. Coding for $L$. chavezi is either $=1$ or $=2$, the latter in recognition of putative convergence and independent derivation of this pattern of development; see alternative coding in Table II.

23. Bursal lobes, ventral structure and ornamentation: Two states: 0 $=$ markings absent, or present only as irregular projections, spines, or raised plates, often with reticulate striations along bursal margin; $1=$ markings always composed of discrete, raised cuticular bosses disposed on lateral lobes. Sarwar (1956) discussed and reviewed the possible significance of a variety of cuticular markings observed on the internal lateral lobes of the bursa among the Trichostrongylidae (=Trichostrongylina). Stringfellow (1968) concluded that the bursal bosses typical among species of Nematodirus could have utility in taxonomy and in the unequivocal identification of otherwise similar congeners. Among the Nematodirinae, bursal bosses are discrete and prominent, disposed in characteristic patterns on the internal surface of the lateral lobes but never arranged as plates. Such discrete bosses are typical among all genera of the Nematodirinae, but are absent in Lamanema. Among other Molineids, ornamentation of the bursal lobes is represented by spines in some Molineinae, small triangular spines in Anoplostrongylinae, or small projections and a bursa with distinctly scalloped margins in the Ollulaninae (Sarwar, 1956). Where bursal ornamentation has been observed among other trichostrongylines, it is composed of large plaques or platelike, continuous and irregular bosses among some Ostertagiinae, minute bosses with marginal reticular striations among Cooperiinae, rows of superimposed bosses among the Haemonchinae, and by retic- ular striations among the Amidostomatinae (Travassos, 1937; Sarwar, 1956). Consequently, the condition observed among nematodirines is considered as a putative synapomorphy for the subfamily.

\section{RESULTS}

\section{Phylogeny for Nematodirinae}

Exhaustive analysis, based on a matrix where Hennigs's Auxiliary Principle was suspended for specific characters in $\mathrm{La}$ manema (Table II), resulted in 1 MPT (36 steps; CI $=0.94$; RI $=0.93$; excluding phylogenetically uninformative characters, $\mathrm{CI}=0.92$ ) consistent with monophyly for the Nematodirinae (Fig. 1). As a monophyletic group, Nematodirinae was diagnosed by 8 synapomorphies (7 unequivocal; Fig. 1): (1) large eggs (character 10), (2) long filiform spicules (character 12), (3) basal division of the dorsal ray (character 13), (4) symmetrical membrane enveloping the spicule tips (character 14), (5) fused structure of the spicule tips (character 15), (6) absence of the gubernaculum (character 16), (7) development of the thirdstage larva within the egg (character 22), and (8) ornamentation in the form of bosses on the copulatory bursa of males (character 23). Additionally, the neodont (character 1) and corona radiata or perioral denticles (character 2) are well developed in all nematodirines except among species in the basal Murielus. In the context of parsimony analysis, 7 characters were uninformative; characters $4,7,9,18,19$, and 21 represented autapomorphies for respective genera at this level of universality (see Wiley, 1989), whereas character 11 (structure of female tail) is polymorphic within Nematodirus and Murielus. Jackknife resampling and Bremer decay indices revealed strong justification for monophyly of the Nematodirinae (jackknife = 100\%); moderate support for putative relationships for Raus chia + Nematodiroides and Nematodirus + Nematodirella was evident (Fig. 1). Instability is apparent at the node for crown taxa (jackknife $=80 \%$ ) and for Rauschia + Nematodiroides (63\%) (Fig. 1); a tree 1 step longer than the MPT places Rauschia basal to Nematodiroides and Nematodirus + Nematodirella. The genus Lamanema is clearly excluded from the $\mathrm{Ne}-$ matodirinae in the context of coding that defines apomorphic but convergent states for characters 1, 10, 21, and 22 (Fig. 1; Table II). The topology of the trees resulting from both the primary analysis and jackknife resampling was congruent.

Analysis of a matrix specifying alternative coding for $\mathrm{La}$ manema (coding consistent with the Hennig's Auxiliary Principle, where similar structures are considered homologous) resulted in 2 MPTs (35 steps; $\mathrm{CI}=0.86 ; \mathrm{RI}=0.81$; excluding phylogenetically uninformative characters, $\mathrm{CI}=0.81$ ). These trees (not shown) placed (1) Trichostrongyloidea and Lamane$m a$ in a basal polytomy with the Molineoidea as the sister group of the nematodirines or (2) Lamanema as the sister for the nematodirines. A strict consensus of these hypotheses placed Trichostrongyloidea, Molineoidea, and Lamanema in a basal polytomy and supported monophyly for the Nematodirinae (tree not shown). Jackknife resampling resulted in a strict consensus tree placing Lamanema as the sister group for the inclusive Nematodirinae, although the node was supported in only $51 \%$ of the replicates and the Bremer decay value $=0$. In contrast, the values for Bremer decay and jackknife were 4 steps and $98 \%$, respectively, in defining a monophyletic Nematodirinae with 5 genera; topology and support for relationships of these 


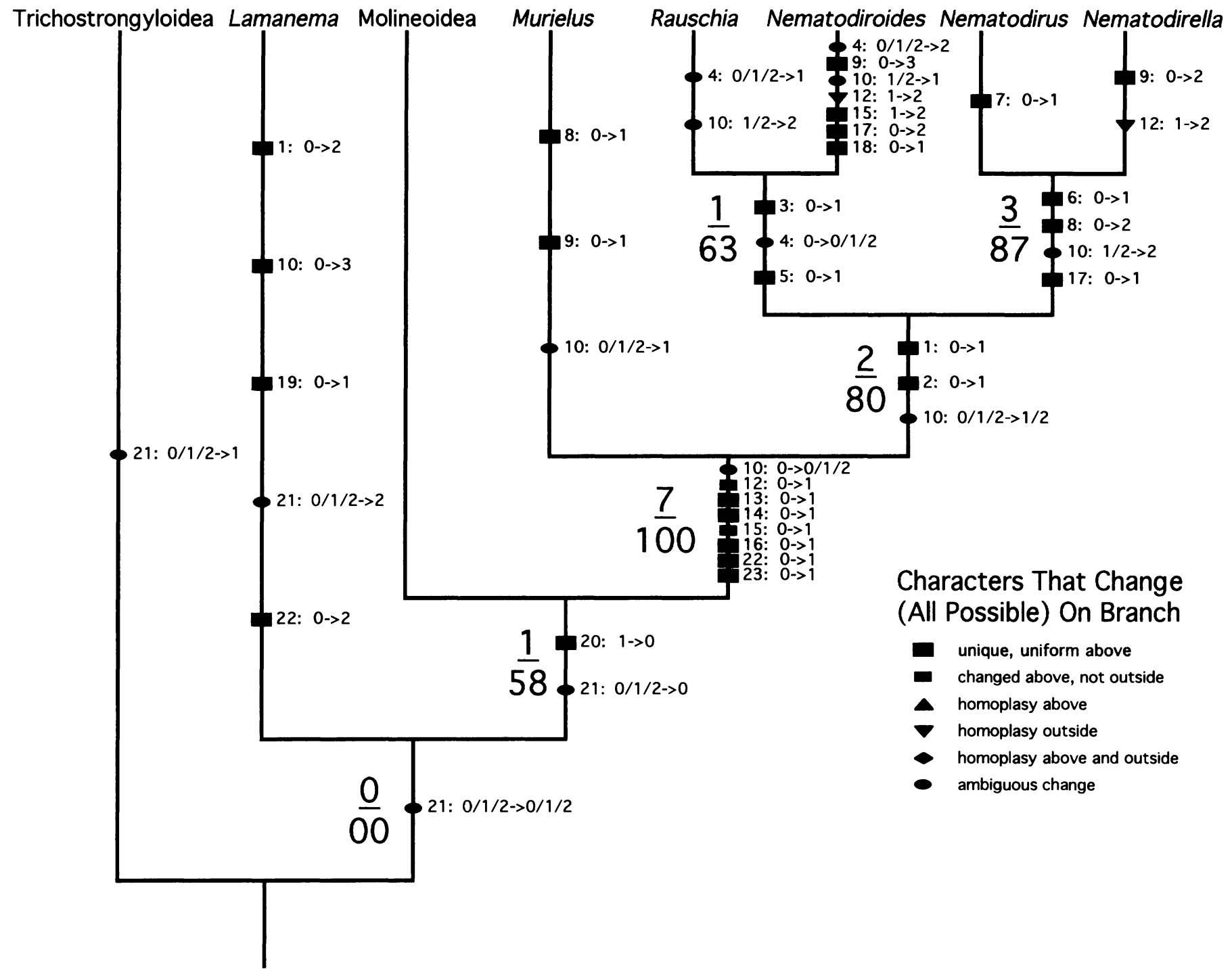

FIGURE 1. Phylogeny for genera of the Nematodirinae based on analysis of characters from comparative morphology. The fully resolved and single most parsimonious tree (36 steps; CI excluding uninformative characters $=0.92$ ) depicts putative relationships among genera of the Nematodirinae and is consistent with monophyly for the subfamily. Characters have been mapped directly onto the tree with MacClade 4.0 (Maddison and Maddison, 2000). Note there are 8 synapomorphies, with 7 unequivocal, for phylogenetic diagnosis of the Nematodirinae. Refer to character matrix (Table II) and descriptions in text for explanations. Attributes that diagnose specific nodes are numbered and putative transformations are indicated by arrows. The distribution of apomorphic (as putative synapomorphy and autapomorphy), homplasious, and ambiguous character states is indicated on the tree for each structural or developmental attribute (see key and symbols on figure). Values shown to the left of each node are those for Bremer decay indices, as steps required to collapse the tree (above), and jackknife resampling, as a percentage based on 10,000 replicates (below). Monophyly for Nematodirinae was strongly supported ( 7 steps and 100\%); inclusion of the genus Lamanema in Nematodirinae lacks support.

inclusive taxa were largely identical to that revealed in the primary analysis.

Analyses did not refute the exclusion of the monotypic $L a-$ manema from the Nematodirinae. Lamanema chavezi lacks putative synapomorphies that constitute phylogenetic diagnosis for the Nematodirinae (Fig. 1). Characters 1 (neodont), 10 (large eggs), 21 (divergence of rays 2/3), and 22 (development of the L3) are ambiguous with respect to placement of $L$. chav$e z i$ based on either reconstruction resulting from alternatives in coding. This suite of characters also exhibits homoplasy relative to a restricted number of unrelated taxa within the Strongylida and Trichostrongylina. Lamanema possesses large eggs and a neodont but lacks unequivocal characters that are phylogenetically informative for demonstrating a relationship to the nematodirines.

\section{Character evolution and relationships}

Relationships among genera of nematodirines appear well resolved (Fig. 1): Murielus is basal; and 2 subclades, Rauschia + Nematodiroides and Nematodirus + Nematodirella are sister groups diagnosed by presence of a neodont and corona radiata 
(characters 1, 2). Rauschia + Nematodrioides is diagnosed by orientation and gradient in the synlophe (characters 3,5). Nematodirus + Nematodirella is diagnosed by a high number of ridges in the synlophe (character 6), position of the vulva at the midbody or in the anterior (character 8 ), and bursal rays 4 and 5 of equal size (character 17). Each of the genera is further diagnosed by suites of synapomorphic characters that are shared among congeners. Notably, species of Nematodirella are diagnosed by extremely long spicules (character 9) and species of Nematodirus may be diagnosed by the presence of finlike ridges (character 7) comprising the synlophe in the dorsal and ventral field. This latter attribute, however, may occur only among a limited number of species and, thus, may be polymorphic in the genus, and as such, may constitute equivocal support for Nematodirus. Rauschia lacks unequivocal synapomorphies based on this analysis; a ventrolateral orientation of the synlophe (character 4) and extremely large eggs (character 10) characterize all species, but the derivation of the apomorphic condition for these attributes is considered to be ambiguous (Fig. 1).

Two genera, Murielus and Nematodirus, apparently represent multistate taxa, where respective species possess either a conical or truncate tail with spine (character 11). Although the truncate state is a putative synapomorphy for Molineoidea (Gouy de Bellocq et al., 2001), it represents the plesiomorphic state for the Nematodirinae based on the concept of universality (see Wiley, 1979). Thus, polymorphism is attributable to independent origins of the conical tail from the truncate tail with spine in species of Murielus and Nematodrius.

Homoplasy was represented in 2 attributes, including the spicule length (character 12) and length of eggs (character 10). Extreme length of spicules, $\geq 4 \mathrm{~mm}$, represents parallel development in Nematodiroides zembrae and species of Nematodirella. Additionally, species of 3 genera, Rauschia, Nematodrius, and Nematodirella, are characterized by eggs generally $\geq 200$ $\mu \mathrm{m}$ in length (character 10 ); relatively smaller eggs in Nematodiroides represent a putative reversal.

\section{DISCUSSION}

\section{Phylogenetic diagnosis for Nematodirinae}

Monophyly for the Nematodirinae, with 5 genera, was confirmed in the current study based on comparative morphology and phylogenetic analysis of structural characters (Fig. 1). This concept for the nematodirines excludes the monotypic $L$. chav$e z i$, but otherwise corroborates generic-level diversity as defined in prior studies (e.g., Durette-Desset and Chabaud, 1977, 1981a; Durette-Desset, 1985). Additionally, results of our phylogenetic analyses in part confirm the preliminary conclusions about character support and recognition of synapomorphies for diagnosis of Nematodirinae (Rickard and Hoberg, 2000).

The morphology of $L$. chavezi has been considered highly divergent and enigmatic with respect to the nematodirines and other molineoids or trichostrongyloids (Becklund, 1963; Durette-Desset, 1978; Sutton and Durette-Desset, 1985; Rickard and Hoberg, 2000). Based on the structure of the synlophe and esophageal tooth, Durette-Desset (1978) considered Lamanema as a transitional form linking Nematodirinae and Molineinae. Subsequently, absence of the corona radiata and the structure of the synlophe led Durette-Desset and Chabaud (1981a), Dur-
ette-Desset (1985), and Sutton and Durette-Desset (1985) to conclude that Lamanema represented the most primitive member of the Nematodirinae. These plesiomorphic characters, however, would have no bearing on understanding the putative relationships for Lamanema with either the nematodirines or other Trichostrongylina; the presence of a neodont represents an independently derived character within the Nematodirinae and Haemonchinae (Durette-Desset, 1983, 1985). Rickard and Hoberg (2000) offered an alternative hypothesis for relationships of $L$. chavezi based on approaches from comparative morphology and suggested placement of the genus within the Molineinae, but not as a transitional form.

The present analyses provided the first explicit test of monophyly for Nematodirinae and of the range of alternative concepts for Lamanema. Powerful jackknife and Bremer support are apparent for recognition of the Nematodirinae (Fig. 1). Lamanema is consistently excluded from the Nematodirinae irrespective of the conventions used for character coding and whether or not Hennig's Auxiliary Principle is enforced (Table II); suspension of the Auxiliary Principle in the context of coding for this monotypic genus appears warranted (Brooks and McLennan, 2002). There is no apparent phylogenetic basis for Lamanema as a nematodirine, but the current analyses have failed to reveal an unequivocal linkage to other taxa within the Trichostrongylina. Durette-Desset (1985) and Rickard and Hoberg (2000) would both suggest affinities to the Molineinae, and a series of more extensive phylogenetic studies designed explicitly to examine the relations for Lamanema are requisite but are beyond the scope of the current analyses.

Monophyly for nematodirines is linked to 7 unequivocal synapomorphies that constitute phylogenetic diagnosis for the subfamily (Fig. 1). Analysis corroborated exclusion of the monotypic Lamanema, as L. chavezi lacks 6 of the 7 unequivocal synapomorphies that diagnose the Nematodirinae (Rickard and Hoberg, 2000). Additionally, autapomorphies including the divergence of bursal rays 2 and 3 (character 21 ), structure of the accessory bursal membrane (character 20 ), and a unique pattern of enterohepatic development (character 19) further define the distinct nature of Lamanema. In this regard, hypotheses for independent derivation of several characters may warrant further examination.

We assume here that large eggs (character 10) have been independently derived in the Molineinae (Lamanema), Trichostrongyloidea (species of Marshallagia Orloff, 1933), and in genera and species of the Nematodirinae. Extended development and molting of late larval stages also appears to be associated with those species in which large eggs are typical. In Lamanema and probably all Nematodirines (data are not available for Murielus and Nematodiroides), development to the infective third larval stage occurs within the egg (character 22). Among species of Marshallagia, eggs are up to $200 \mu \mathrm{m}$ in length and hatching is delayed until the second larval stage (Skrjabin et al., 1954). Large eggs, in conjunction with delayed hatching, may represent specific adaptations for enhancing survival and transmission in extreme environments (see below). We postulate that this pattern of ontogeny is convergent where it occurs across the Trichostrongylina, particularly when considered within the context of a suite of other characters.

The neodont (character 1) is also regarded as homoplasious within the Trichostrongylina, consistent with hypotheses out- 
lined by Durette-Desset (1985) and Durette-Desset et al. (1994). The esophageal structure, found among the Haemonchinae (Trichostrongyloidea), Nematodirinae (excluding Murielus), and Lamanema (Molineinae) is not considered an indicator of common ancestry.

The structure of the bursa and, specifically, the highly divergent disposition of rays 2 and 3 (character 21), is not often observed among the Trichostrongylina. In specimens of $\mathrm{La}$ manema, rays 2 and 3 are relatively robust and curved anteriorly, with the tips strongly separated. Among some Trichostrongyloidea, including the Haemonchinae, some Cooperiinae, Pseudostertagia bullosa (Ransom and Hall, 1912), and Parostertagia heterospiculum Schwartz and Alicata, 1933, a similar pattern for rays 2 and 3 has been noted (Gibbons and Khalil, 1982). In contrast, rays 2 and 3 are parallel and narrow among nematodirines and most Molineoidea, which represents the plesiomorphic condition (Durette-Desset et al., 1999). Additionally, an accessory bursal membrane (character 20) associated with dorsal papillae (rays 7) in Lamanema is apomorphic and similar to that observed in Trichostrongyloidea (see Hoberg and Lichtenfels, 1994).

Life history patterns are relatively uniform among trichostrongylines and progression of infections and ontogeny of parasitic larvae are usually limited to the lumen or mucosa of the gastrointestinal system. Among trichostrongyloid parasites in artiodactyls, an enterohepatic cycle is only seen in Cooperioides hepaticae, where development of parasitic stages occurs in the lumen of the small intestine, but immature adults migrate into the bile ducts prior to patency (Anderson, 1992). The enterohepatic cycle in $L$. chavezi (character 19) differs considerably as third-stage larvae migrate via the circulation to the liver, molt to the fourth stage in the hepatic parenchyma, and then return to the small intestine to complete development (Guerrero et al., 1973).

Durette-Desset (1978) and Sutton and Durette-Desset (1985) concluded that Lamanema represented a transitional form between the Molineinae and Nematodirinae. This contention of a relationship for Lamanema and basal nematodrines appears to be refuted by the present analyses (Fig. 1). Consequently, the historical relationships for the nematodirines require further examination, as the former conclusion figured prominently in hypotheses about evolution of these nematodes, a putative ancestral association with camelids, and a relictual status for Nematodirus lamae in the Neotropical region (e.g., Rossi, 1983; Durette-Desset, 1985; Durette-Desset et al., 1994).

\section{ACKNOWLEDGMENTS}

We thank M. Cristina D'Amborenea, Curator, Collecion Helmintologia del Muséo de La Plata, Argentina, for loaning specimens of $L$. chavezi from Lagidium viscacia. Additional specimens were made available by L. M. Gibbons from the former helminthological collections at the International Institute of Parasitology, St. Albans, United Kingdom. We thank Arthur Abrams of the USNPC for assistance in preparing specimens during the present study.

\section{LITERATURE CITED}

Anderson, I. G. 1992. Observations on the life cycles and larval morphogenesis of, and transmission experiments with Cooperioides hamiltoni and Cooperioides hepaticae (Nematoda: Trichostrongyloidea) parasitic in impala, Aepyceros melampus. South Africa Journal of Zoology 27: 81-88.
Audebert, F., M.-C. Durette-Desset, and N. B. Chilton. 2000. Internal transcribed space rDNA can be used to infer the phylogenetic relationships of species within the genus Nematodirus (Nematoda: Molineoidea). International Journal for Parasitology 30: 187-191.

BECKLUND, W. W. 1963. Lamanema chavezi gen. n. et sp. n. and Nematodirus lamae sp. n. (Nematoda: Trichostrongyloidea) from the alpaca, Lama pacos, and the vicuña, Vicugna vicugna, in Peru. Journal of Parasitology 49: 1023-1027.

BERNARD, J. 1967. Note complémentaire au sujet de Nematodirus $(=\mathrm{Ne}$ matodiroides n. gen.) zembrae. Archives de l'Institute Pasteur de Tunis 44: 443-447.

BREMER, K. 1994. Branch support and tree stability. Cladistics 10: $295-$ 304.

Brooks, D. R., AND E. P. Hoberg. 2000. Triage for the biosphere: The need and rationale for taxonomic inventories and phylogenetic studies of parasites. Comparative Parasitology 67: 1-25.

- AND D. A. MCLenNan. 2002. The nature of diversity: An evolutionary voyage of discovery. University of Chicago Press, Chicago, Illinois, $668 \mathrm{p}$.

Chabaud, A. G., O. Bain, and F. Puylaert. 1967. De trois nouveaux nématodes Molineinae et considérations sur la systématique et le caractère archaïque de cette sous-famille. Bulletin du Muséum National d'Histoire Naturelle 38: 904-920.

DuRETTE-Desset, M.-C. 1974. Murielus abei n. sp. (Nematoda: Heligmosomidae), parasite d'un lagomorphe du Népal, et remarques sur le genre Murielus Dikmans, 1939. Bulletin du Muséum National d'Histoire Naturelle 144: 419-424.

- 1978. Nouvelles données morphologiques sur les nématodes Trichostrongyloides des collections du United States National Museum. Bulletin du Muséum National d'Histoire Naturelle, Series 3, Zoologie 352: 135-147.

- 1979. Les Nematodirinae (Nematoda) chez ruminants et chez les lagomorphes. Annales de Parasitologie Humaine et Comparée 54: 313-339.

-1983. Keys to the genera of the superfamily Trichostrongyloidea. No. 10. CIH keys to the nematode parasites of vertebrates, $R$. C. Anderson and A. G. Chabaud (eds.). Commonwealth Agricultural Bureaux, Farnham Royal, U.K., 86 p.

- 1985. Trichostrongyloid nematodes and their vertebrate hosts: Reconstruction of the phylogeny of a parasite group. Advances in Parasitology 24: 239-306.

- I. Beveridge, AND D. M. SpRatT. 1994. The origins and evolutionary expansion of the Strongylida (Nematoda). International Journal of Parasitology 24: 1139-1165.

, AND A. G. Chabaud. 1977. Essai de classification des Nématodes Trichostrongyloidea. Annales de Parasitologie Humaine et Comparée 52: 539-558.

— AND — 1981a. Nouvel essai de classification des Nématodes Trichostrongyloidea. Annales de Parasitologie Humaine et Comparée 56: 297-312.

— AND $1981 \mathrm{~b}$. Sur les Molineinae parasites de mammiféres. Annales de Parasitologie Humaine et Comparée 56: 489502.

— AND — 1993. Nomenclature des Strongylida au-dessus du groupe-famille. Annales de Parasitologie Humaine et Comparée 68: $111-112$.

- J. P. Hugot, P. Darlu, and A. G. Chabaud. 1999. A cladistic analysis of the Trichostrongyloidea (Nematoda). International Journal for Parasitology 29: 1065-1086.

GibBons, L. M., AND L. F. Khalil. 1982. A key for the identification of genera of the nematode family Trichostrongylidae Leiper, 1912. Journal of Helminthology 56: 185-233.

GouŸ de BellocQ, J., H. Ferté, J. Depaquit, J.-L. Justine, A. Tillier, And M.-C. Durette-Desset. 2001. Phylogeny of the Trichostrongylina (Nematoda) inferred from 28S rDNA sequences. Molecular Phylogenetics and Evolution 19: 430-442.

Guerrero, C. A., J. Alva, I. Vega, J. Hernandez, and M. Rojas. 1973. Algunos aspectos biologicos y patologicos del Lamanema chavezi en alpacas, Lama pacos. Rev. Inv. Pec. (IVITA) Univ. Nec. S. Marcos 2: 29-42.

, M. Rojas, AND J. Alva. 1981. Lamanema chavezi, an enterohepatic nematode of South American Camelidae and its control 
using levamisole. Revista Latin American Microbiology 23: 121123.

HOBERG, E. P. 1997. Parasite biodiversity and emerging pathogens: a role for systematics in limiting impacts on genetic resources. In Global genetic resources: access, ownership and intellectual property rights, K. E. Hoaglund and A. Y. Rossman (eds.). Association of Systematics Collections, Washington, D. C., p. 71-83.

, AND J. R. LICHTENFELS. 1994. Phylogenetic systematic analysis of the Trichostrongylidae (Nematoda), with an initial assessment of coevolution and biogeography. Journal of Parasitology 80: 976996.

, G. L. Zimmerman, AND L. G. Rickard. 1985. Nematodiru battus: A review of recent studies relative to the development of surveillance and control programs. Proceedings of the United States Animal Health Association 89: 420-431.

Lichtenfels, J. R., AND P. A. PilitT. 1983a. Cuticular ridge patterns of Nematodirus (Nematoda: Trichostrongyloidea) parasitic in domestic ruminants of North America, with a key to species. Proceedings of the Helminthological Society of Washington 50: 261-274.

, AND - 1983b. Cuticular ridge patterns of Nematodirella (Nematoda: Trichostrongyloidea) of North American ruminants, with a key to species. Systematic Parasitology 5: 271-285.

Maddison, D. R., AND W. P. MAdDISON. 2000. MacClade 4.0, program and manual. Sinauer and Associates, Sunderland, Massachusetts, $492 \mathrm{p}$.

Maddison, W. P. M., M. J. Donoghue, and D. R. Maddison. 1984. Outgroup analysis and parsimony. Systematic Zoology 33: 83-103.

Nadler, S. A., E. P. Hoberg, D. S. S. Hudspeth, and L. G. Rickard. 2000. Relationships of Nematodirus species and Nematodirus battus isolates (Nematoda: Trichostrongyloidea) based on nuclear ribosomal DNA sequences. Journal of Parasitology 86: 588-601.

RiCKARD, L. G., AND E. P. HoberG. 2000. Reassignment of Lamanema from Nematodirinae to Molineinae (Nematoda: Trichostrongyloidea). Journal of Parasitology 86: 647-650.

, J. K. Bishop, AND G. L. ZimMERMAN. 1989. Epizootiology of Nematodirus battus, $N$. filicollis, and N. spathiger (Nem- atoda: Trichostrongyloidea) in western Oregon. Proceedings of the Helminthological Society of Washington 56: 104-115.

Rossi, P. 1983. Sur le genre Nematodirus Ransom, 1907 (Nematoda: Trichostrongyloidea). Annales de Parasitologie Humaine et Comparée 58: 557-581.

SARWAR, M. M. 1956. Studies on some trichostrongylids of ruminants from the Indo-Pakistan sub-continent. Biologia 2: 145-215.

SkrJabin, K. I., N. P. Shikhobalova, and R. S. Shul'ts. 1954. Trichostrongylids of animals and man. Isdatel'stvo Akademii Nauk SSSR, Moskva. [English Translation: 1960. The Israel Program for Scientific Translations, Jerusalem, 704 p.].

STRINGFEllow, F. 1968. Bursal bosses as a diagnostic character in Nematodirus of domestic sheep, Ovis aries, in the United States. Journal of Parastology 54: 891-895.

Sutton, C. A., AND M.-C. DuRetTe-Desset. 1985. Contribucion al conocimiento de la fauna parasitological Argentina XIV. Precencia de Lamanema chavezi Becklund, 1963 (Nematoda: Molineidae, Nematodirinae) parasito de camelidos en Lagidium viscacia boxi. Bulletin du Muséum National d'Histoire Naturelle, Série 7 Séction A4: 791-794.

SWOFFORD, D. D. 2001. PAUP 4.0b10 computer program for MacIntosh. Sinauer and Associates, Sunderland, Massachusetts.

Thomas, R. J. 1959. A comparative study of the life histories of Nematodirus battus and $N$. filicollis, nematode parasites of sheep. Parasitology 49: 374-386.

- AND A. J. STEVENS. 1956. Some observations on Nematodirus disease in Northumberland and Durham. Veterinary Record 68: 471-475.

Travassos, L. 1937. Revisão da familia Trichostrongylidae Leiper, 1912. Mongrafias do Instituto Oswaldo Cruz 1, $512 \mathrm{p}$.

Watrous, L. E., AND Q. D. WheElER. 1981. The outgroup comparison method of character analysis. Systematic Zoology 30: 1-11.

WILEY, E. O. 1989. Phylogenetics: The theory and practice of phylogenetic systematics. Wiley Interscience, New York, New York, 439 p.

, D. Siegel-Causey, D. R. Brooks, and V. A. FunK. 1991. The complete cladist: A primer of phylogenetic procedures. University of Kansas Press, Lawrence, Kansas, 158 p. 